\title{
Serum and alveolar IGA and IGG2 levels may help to predict ventilator-associated pneumonia outcome
}

\author{
M Gordon Sahuquillo', C Lopez Ferraz', J Bermejo-Martin², M Moreno', I Paredes', E Villarreal Tello', C Calabuig', \\ J Ruiz Ramos ${ }^{1}$, A Cortes ${ }^{1 *}$, P Geffner ${ }^{1}$, A Castellanos Ortega'1', P Ramirez Galleymore ${ }^{1}$
}

From ESICM LIVES 2015

Berlin, Germany. 3-7 October 2015

\section{Introduction}

There is an emerging evidence that critical illnes induces an alteration in the immune response of patients that makes them more susceptible to the development of nosocomial infections and influences its clinical response.

\section{Objectives}

The aim of this study is to characterize the immunocompetence status of critically ill patients undergoing mechanical ventilation and to determine impaired immune patterns associated with an increased risk of developing ventilator-associated pneumonia (VAP) and a poorer clinical evolution.

\section{Methods}

All immunocompetent patients over 18 years old admitted to the Intensive Care Unit of the Hospital Universitario and Politecnico la Fe (Valencia, Spain), undergoing mechanical ventilation for more than 48 hours were included. Patients with clinical suspicion of ventilatorassociated respiratory infection were considered as cases and compared with a selection of controls matched by age, comorbidities, severity scales and days of mechanical ventilation. At the moment of intubation and each 72 hours until the moment of extubation, clinical surveillance was performed and respiratory samples (minibronchoalveolar lavage, mini-BAL) were taken to evaluate clinical and microbiological response. Samples of plasma and mini-BAL were also taken for immunoglobulins IgG1 - IgG4, IgM, IgA and IgE determination. Comparison of

${ }^{1}$ Hospital Universitari i Politècnic La Fe, Critical Care Medicine, Valencia, Spain Full list of author information is available at the end of the article numerical and categorical variables was performed with the Mann-Whitney U test. Results were expressed as medians with interquartile (25\% to $75 \%$ ) ranges (IR) in brackets.

\section{Results}

16 cases and 14 controls were considered for analysis. Response to antibiotic treatment was evaluated in cases and patients were classified in responders ( 7 cases) and non-responders (8 cases). Initial empirical antibiotic treatment was more accurate in responders patients (85.7\% vs. $50 \%$; p 0.559$)$. At the moment of orotracheal intubation and beginning of mechanical ventilation, VAP patients showed lower serum IgA levels $(284 \mathrm{mg} / \mathrm{dl}$ [162 - 664] vs. $663 \mathrm{mg} / \mathrm{dl}$ [475 - 1,259]; p 0.049) (figure A), lower serum IgG1 and IgM and lower respiratory levels of IgG1, IgG2 and IgA, without statistical signification. At the moment of VAP diagnosis, responders patients showed higher levels of IgG2 $(123 \mathrm{mg} / \mathrm{dl}[64$ 235] vs. $41 \mathrm{mg} / \mathrm{dl}$ [32 - 60]; p 0.037) (figure B), lower serum IgG1 and IgM (without statistical signification) and higher levels of IgA $(1,900 \mathrm{mg} / \mathrm{dl}[536$ - 1,900] vs. 22 $\mathrm{ng} / \mathrm{ml}[3$ - 589]; p 0.036) (figure C).

\section{Conclusion}

Our findings show the protective role of IgA and IgG2 against the inflammatory aggression of mechanical ventilation and in the response against ventilator-associated pneumonia.

\section{Grant Acknowledgment}

This study was supported by the Spanish Society of Pneumology and Thoracic Surgery (SEPAR 129/2011).

\section{SpringerOpen ${ }^{\odot}$}

(0) 2015 Gordon Sahuquillo et al.; This is an Open Access article distributed under the terms of the Creative Commons Attribution License (http://creativecommons.org/licenses/by/4.0), which permits unrestricted use, distribution, and reproduction in any medium, provided the original work is properly cited. 

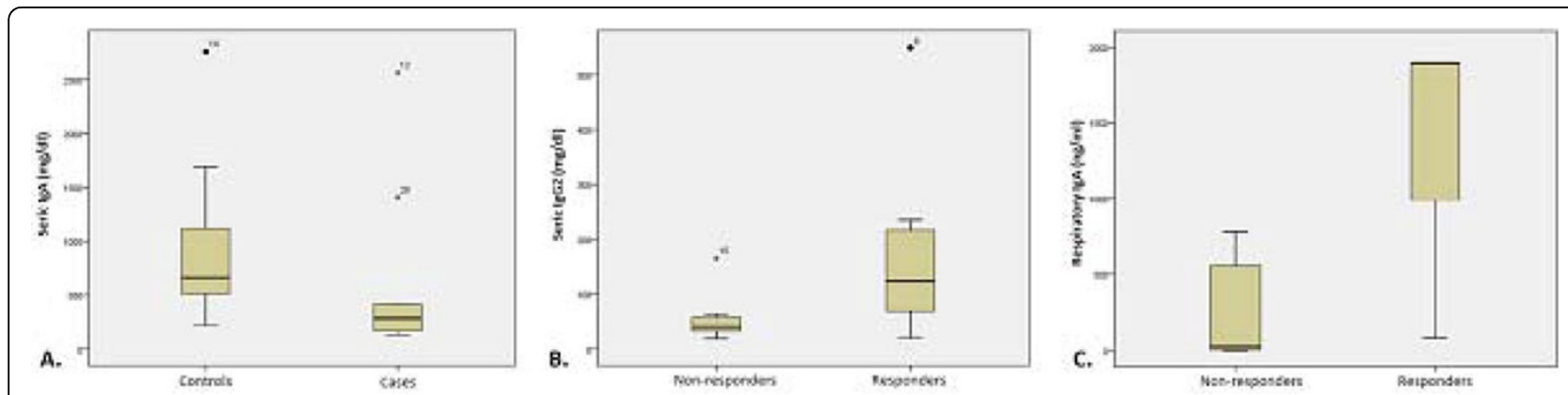

Figure 1 Seric and respiratory Ig levels

\section{Authors' details}

${ }^{1}$ Hospital Universitari i Politècnic La Fe, Critical Care Medicine, Valencia,

Spain. ${ }^{2}$ Hospital Clínico Universitario de Valladolid, Unidad de Investigación

Biomédica del Clínico, Valencia, Spain.

Published: 1 October 2015

doi:10.1186/2197-425X-3-S1-A873

Cite this article as: Gordon Sahuquillo et al: Serum and alveolar IGA and

IGG2 levels may help to predict ventilator-associated pneumonia

outcome. Intensive Care Medicine Experimental 2015 3(Suppl 1):A873.

\section{Submit your manuscript to a SpringerOpen ${ }^{\mathcal{O}}$ journal and benefit from:}

- Convenient online submission

- Rigorous peer review

- Immediate publication on acceptance

- Open access: articles freely available online

- High visibility within the field

- Retaining the copyright to your article

Submit your next manuscript at $\gg$ springeropen.com 